\title{
ASPEK LEGALITAS TERHADAP PELAYANAN KESEHATAN TRADISIONAL DI INDONESIA
}

\author{
Istiana Heriani; Munajah \\ Lecturer of Law Faculty, University of IslamKalimantan, South Kalimantan \\ E-mail: iheriani2579@gmail.com
}

\begin{abstract}
Traditional health services in Indonesia have been regulated in the Law No. 36 of 2009 about Health and in Minister of Health regulated No. 15 of 2018 about the implementation oc complementary traditional health. This paper isintended to discuss the legal protection of traditional health services and its forms. This study applies normative juridical methods. The results show that the level of legal protection for traditional health services is empirically lower than complementary and integration. This is proven by the absence of the right to obtain legal protection for traditional empirical health services. The legality of traditional empirical health servicesis only attested by Traditional Health Registered Letters (STPT) while complementary and integration is attested by a Certificate of Traditional Health Worker Registration(STRTKT) and Practice Permit Traditional Health Workers (SIPTKT).
\end{abstract}

Keywords: rights and legality; traditional health services; legal protection

\begin{abstract}
Abstrak
Pelayanan kesehatan tradisional di Indonesia telah diatur dalam peraturan perundangundangan Indonesia,yakni dalam Undang-Undang No. 36 Tahun 2009 tentang Kesehatan dan diatur secara lebih rinci dalam Peraturan Menteri Kesehatan Republik Indonesia No. 15 Tahun 2018 tentang Penyelenggaraan Kesehatan Tradisional Komplementer. Permasalahan yangdiangkat dalam penelitian ini adalah tentang aspek legalitas terhadap pelayanan kesehatan tradisional serta bagaimana bentuk-bentuk perlindungan hukumnya. Penelitian ini menggunakan metode yuridis normatif.Hasil penelitian menunjukkan bahwa tingkat legalitas terhadap pelayanan kesehatan tradisional empiris lebih rendah dibandingkan dengan komplementer dan integrasi. Hal tersebut dibuktikan dengan tidak adanya hak memperoleh perlindungan hukum bagi pelayanan kesehatan tradisional empiris dan legalitas pelayanan kesehatan tradisional empiris hanya dibuktikan dengan Surat Terdaftar Penyehat Tradisional (STPT) sedangkan komplementer dan integrasi dibuktikan dengan Surat Tanda Registrasi Tenaga Kesehatan Tradisional (STRTKT) danSurat Izin Praktik Tenaga Kesehatan Tradisional (SIPTKT).
\end{abstract}

Kata kunci: hak dan legalitas; pelayanan kesehatan tradisional; perlindungan hukum 


\section{PENDAHULUAN}

Kesehatan adalah kebutuhan setiap manusia yang harus dipenuhi.Sebagaimana dimaksud dalam Pancasila dan UndangUndang Dasar Negara Kesatuan Republik Indonesia Tahun 1945, bahwa kesehatan merupakan hak asasi manusia, salah satu unsur kesejahteraan yang harus diwujudkan sesuai dengan cita-cita bangsa Indonesia. Meskipun sama fundamentalnya dengan hak-hak yang lain, hak atas pelayanan kesehatan sering dianggap lebih mendasar. ${ }^{1}$ Oleh karena itu, hak atas pelayanan kesehatan merupakan suatu hal yang harus dimiliki oleh setiap warganegara Indonesia. Sehingga tidak ada masyarakat yang tidak bisa melakukan pengobatan.

Pengobatan yang dapat dilakukan oleh masyarakat dapat berupa bantuan medis ataupun pengobatan secara tradisional. Meskipun memiliki metode pengobatan yang berbeda, keduanya memiliki tujuan yang sama yaitu untuk memberikan pelayanan kesehatan terbaik bagi seorang pasien.

Pengobatan tradisional pada awalnya telah dikenal oleh masyarakat Indonesia sejak munculnya pemahaman pengobatan yang bersifat mistik dan

${ }^{1}$ Ari Yunanto, 2010, Hukum Pidana MalpraktikMedik (Tinjauan dan Perspektif Medikolegal, Yogyakarta: Penerbit Andi, hlm. 19. kepercayaan pada tenaga gaib yang berakar pada animisme. Pada perkembangannya, pengobatan tradisional di Indonesia banyak dipengaruhi oleh budaya asing, seperti India, Cina, Timur Tengah (Arab) dan Eropa. ${ }^{2}$ Seiring dengan berjalannya waktu, semakin banyak usaha dalam bidang pelayanan kesehatan tradisional diIndonesia. Umumnya, pengobatan tradisional menawarkan harga yang lebih terjangkau dibandingkan dengan pengobatan komplementer dan integrasi. Dengan semakin meningkatnya biaya pengobatan kesehatan, masyarakat banyak beralih kepada pelayanan pengobatan tradisional.

Sejak tahun 2009, pelayanan kesehatan tradisional diatur dalam peraturan per undang-undangan, yakni Undang-Undang No. 36 Tahun 2009 tentang Kesehatan. Pasal 1 angka 16 Undang-Undang No. 36 Tahun 2009 tentang Kesehatan menentukan bahwa pelayanan kesehatan tradisional adalah pengobatan dan/atau perawatan dengan cara dan obat yang mengacu pada pengalaman dan keterampilan turun temurun secara empiris yang dapat dipertanggungjawabkan dan diterapkan

${ }^{2}$ Cecep Triwibowo, 2014, Etika \& HukumKesehatan, Yogyakarta: Medical Book, hlm. 137. 
sesuai dengan norma yang berlaku di masyarakat.

Berdasarkan ketentuan tersebut, dapat dijabarkan bahwa pengertian pelayanan kesehatan tradisional mengandung persyaratan:

1. Adanya aktifitas pengobatan dan atau perawatan;

2. Menggunakan cara atau obat tradisional;

3. Berdasarkan pengalaman dan keterampilan turun-temurun;

4. Dapat dipertanggung jawabkan secara empiris; dan

5. Penerapannya sesuai dengan norma yang berlaku di masyarakat.

Ketentuan mengenai pengobatan tradisional juga ditetapkan dengan Keputusan Menteri Kesehatan Nomor 15 Tahun 2018 tentang Penyelenggaraan pengobatan Tradisional Komplementer.

Adapun tujuan dari KepMenKes tersebut adalah sebagai upaya untuk membina pengobatan tradisional, memberikan perlindungan kepada masyarakat, menginventarisasikan jumlah pengobatan tradisional, serta jenis dan cara pengobatannya.

Dengan meningkatnya pemanfaatan layanan kesehatan tradisional tentu saja perlu dibarengi dengan kajian penguatan hukum terhadapnya. Perannya sebagai salah satu tenaga kesehatan masyarakat perlu didorong dan dijamin secara legal. Selain isu keamanan dan keselamatan konsumen, seorang pengobat tradisional perlu mendapatkan perlindungan hukum terhadap profesinya.

Berdasarkan uraian di atas, pelaku pelayanan kesehatan tradisional memberikan pelayanan berdasarkan pada standar pelayanan kesehatan tradisional yang metodenya telah memenuhi persyaratan penapisan, pengkajian, penelitian dan pengujian serta terbukti aman dan bermanfaat bagi kesehatan yang ditetapkan oleh pemerintah.

Akan tetapi, apabila pasien menderita kerugian, cedera fisik dan bahkan kematian maka pelaku pelayanan kesehatan tradisional bertanggung jawab sepenuhnya atas kerugian tersebut. Hal tersebut menunjukkan bahwa perlindungan hukum bagi pelayanan kesehatan tradisional penting untuk dianalisis secara yuridis.

\section{RUMUSAN MASALAH}

Berdasarkan latar belakang masalah tersebut, maka rumusan masalah dalam penelitian ini adalah:

1. Bagaimana perlindungan hukum bagi pelayanan kesehatan tradisional dalam struktur peraturan perundang-undangan Indonesia? 
2. Apa saja bentuk-bentuk perlindungan hukum bagi pelayanan kesehatan tradisional dan masyarakat?

\section{METODE PENELITIAN}

Metode Penelitian kajian ini menggunakan metode penelitian yuridis normatif. Penelitian ini mengkaji bahan kepustakaan terdiri dari bahan hukum dan ditunjang oleh bahan hukum sekunder yang menyangkut penelitian secara menyeluruh baik diantara peraturan setingkat atau diatasnya dimana obyek kajiannya adalah dokumen-dokumen peraturan-peraturan hukum serta bahanbahan pustaka, suatu peraturan perundang-undangan yang tergolong dalam bahan hukum primer dengan meneliti beberapa undang-undang khususnya terkait dengan hukum kesehatan, pelayanan kesehatan tradisional, konsep hukum serta teori hukum yang ada relevansinya dengan pelayanan kesehatan tradisional.

Adapun selanjutnya penulis menggunakan pendekatan perundangundangan dengan menggunakan legislasi dan regulasi. Teknik pengumpulan bahan hukum menggunakan metode sistematis, yakni berupa pengumpulan bahan peraturan perundang - undangan yang menyangkut pengaturan mengenai hukum kesehatan, pelayanan kesehatan tradisional, konsep hukum serta teori hukum yang ada relevansinya dengan pelayanan kesehatan tradisional.Teknik analisis bahan hukum yang digunakan adalah teknik deskripsi, dengan digunakannya teknik ini peneliti menguraikan secara apa adanya terhadap suatu kondisi atau posisi dan proposisiproposisi hukum atau non-hukum.

\section{PEMBAHASAN}

\section{Aspek Legalitas Bagi Pelayanan}

\section{Kesehatan Tradisional dalam Struktur}

Peraturan

Perundang-undangan

Indonesia

Keberadaan hukum dalam masyarakat adalah untuk mengintegrasikan dan mengkoordinasikan kepentingankepentingan seluruh anggota masyarakat. Oleh karena itu, perlu pengaturan terhadap kepentingan-kepentingan yang seharusnya berdasarkan pada keseimbangan antara yang member kebebasan pada individu dan melindungi kepentingan masyarakat. Tatanan hukum tersebut baru menjadi kenyataan manakala subjek hukum diberi hak dan kewajiban. ${ }^{3}$

Aspek legalitas merupakan hak bagi setiap warga negara, dimana setiap

\footnotetext{
${ }^{3}$ Yuliati,2005. Kajian Yuridis Perlindungan Hukum Bagi Pasien Dalam Undang-Undang Ri Nomor 29 Tahun 2004 Tentang Praktik Kedokteran Berkaitan Dengan Malpraktik,Malang: Fakultas Hukum Universitas Brawijaya, hlm. 9.
} 
warga negara berhak untuk memperoleh perlindungan hukum tanpa adanya diskriminatif. Adapun hal tersebut dicantumkan dalam Pasal 28D ayat $1 \mathrm{Bab}$ X A UUD 1945 yang menyatakan bahwa negara berkewajiban untuk memberikan pengakuan jaminan, perlindungan dan kepastian hukum serta keadilan yang mengarah pada perlindungan hukum terhadap negaranya yang meliputi perlindungan kesehatan, perlindungan sosial, perlindungan politik, perlindungan budaya, dan perlindungan lainnya.

\section{Adanya campur tangan Negara} tersebut mempunyai tujuan untuk meningkatkan kesejahteraaan bagi warga negara. Hal tersebut dapat diwujudkan melalui pembentukan sarana hukum, antara lain melalui kebijakan dan penetapan peraturan perundang-undangan yang terkait dengan pelayanan kesehatan tradisional.

Secara normatif, dikeluarkannya pengaturan mengenai penyelenggaraan pelayanan pengobatan tradisional yakni dalam Kepmenkes No. 15 Tahun 2018 Tentang Penyelenggaraan Pengobatan Tradisional Komplementer. Dalam ketentuan tersebut diatur mengenai penertiban ijin pengadaan penyelenggaraan pelayanan kesehatan tradsional. Secara admisnistratif, ini merupakan bentuk perlindungan terhadap para pengguna pelayanan kesehatan tradisional.

Selain dalam Kepmenkes tersebut, Undang-Undang No. 36 Tahun 2009 tentang Kesehatan telah memberikan pengaturan terhadap pelayanan kesehatan tradisional melalui Pasal 59, 60 dan 61.

Pasal 59 Undang-undang No. 36

Tahun 2009 menyebutkan bahwa:

1. Berdasarkan cara pengobatannya, pelayanan kesehatan tradisional terbagi menjadi:

a. pelayanan kesehatan tradisional yang menggunakan keterampilan;

b. pelayanan kesehatan tradisional yang menggunakan ramuan.

2. Pelayanan kesehatan tradisional sebagaimana dimaksud pada ayat (1) dibina dan diawasi oleh Pemerintah agar dapat dipertanggung jawabkan manfaat dan keamanannya serta tidak bertentangan dengan norma agama.

3. Ketentuan lebih lanjut mengenai tatacara dan jenis pelayanan kesehatan tradisional baik itu yang menggunakan keterampilan maupun ramuan diatur dengan Peraturan Pemerintah.

Pasal 60 Undang-undang No. 36 Tahun 2009 menyebutkan bahwa:

1. Setiap orang yang melakukan pelayanan kesehatan tradisional yang menggunakan alat dan teknologi harus mendapat izin dari lembaga kesehatan yang berwenang.

2. Penggunaan alat dan teknologi sebagaimana dimaksud pada ayat (1) harus dapat dipertanggung jawabkan manfaat dan 
keamanannya serta tidak bertentangan dengan norma agama dan kebudayaan masyarakat.

Pasal 61 Undang-undang No. 36

Tahun 2009 menyebutkan bahwa:

1. Masyarakat diberi kesempatan yang seluas-luasnya untuk mengembangkan, meningkatkan dan menggunakan pelayanan kesehatan tradisional yang dapat dipertanggungjawabkan manfaat dan keamanannya.

2. Pemerintah mengatur dan mengawasi pelayanan kesehatan tradisional sebagaimana dimaksud pada ayat (1) dengan didasarkan pada keamanan, kepentingan, dan perlindungan masyarakat.

Ketiga Pasal tersebut mengatur tentang jenis pelayanan kesehatan tradisional, perizinan terhadap penggunaan alat dan teknologi dalam memberikan pelayanan kesehatan, danjuga adanya pengawasan. Oleh karena itu,dengan adanya peraturan tentangpelayanan kesehatan tradisional dalamUU No 36 tahun 2009 merupakan suatubentuk komitmen pemerintah dalam memberikan perlindungan bagi pelayanankesehatan tradisional. Walaupun belum mengatur secara khusus tentang bentuk perlindungannya, namun hal tersebut dapat ditafsirkan secara tersirat.
Ada

beberapa

cara

perlindungansecara hukum, antara lain sebagaiberikut: ${ }^{4}$

1. Membuat peraturan (by givingregulation), yang bertujuan untuk:

a. memberikan hak dan kewajiban;

b. menjamin hak-hak para subyek hukum.

2. Menegakkan peraturan (by the law enforcement)

Pada undang-undang Nomer 36 Tahun 2009 tentang Kesehatan telah diturunkan melalui tahapan Peraturan Pemerintah Nomer 103 tentang Pelayanan Kesehatan Tradisional, namun pelaksanaan peraturan tersebut oleh pihak yang berwenang perlu dipelajari lebih lanjut untuk mendapatkan penjelasan bagaimana pelaksnaan perlindungan hukum difasilitasi oleh pemerintah daerah pada tingkat bawah. Untuk itu diperlukan pengalaman terkait mengenai pelaksanaan perlindungan hukum bagi penyehat pengobatan tradisional di wilayah kabupaten/kota, dimana pemerintah daerah kabupaten/kota memiliki tanggungjawab dan wewenang sebagai pihak/aparatur negara yang diberi amanat untuk melaksanakan perlindungan hukum tersebut dan berhubungan langsung dengan para penyehat pengobatan tradisional.

\footnotetext{
${ }^{4}$ Wahyu Sasongko,2007, Ketentuan-Ketentuan Pokok Hukum Perlindungan Konsumen, BandarLampung: Penerbit Universitas Lampung ,hlm. 31.
} 
Dalam perkembangannya, penerapan kesehatan tradisional berkembang menjadi: (1) Pelayanan Kesehatan Tradisional Empiris, yang manfaat dan keamanannya terbukti secara empiris; dan (2) Pelayanan Kesehatan Tradisional Komplementer, yang manfaat dan keamanannya terbukti secara ilmiah dan memanfaatkan ilmu biomedis.

Berdasarkan hal tersebut, maka pengaturan dalam Peraturan Pemerintah ini mencakup pengaturan dan tata cara serta jenis Pelayanan Kesehatan Tradisional dan Pelayanan Kesehatan Tradisional Komplementer.

Berdasarkan cara pengobatannya, Pelayanan Kesehatan Tradisional Empiris dan Pelayanan Kesehatan Tradisional Komplementer terbagi menjadi: pelayanan yang menggunakan keterampilan; dan (2) pelayanan yang menggunakan ramuan.

Pelayanan Kesehatan Tradisional Empiris dan Pelayanan Kesehatan Tradisional Komplementer harus dibina dan diawasi oleh Pemerintah agar dapat dipertanggungjawabkan manfaat dan keamanannya serta tidak bertentangan dengan norma agama. Kesehatan merupakan bagian penting dari kehidupan, sehingga pengobatan terhadap suatu penyakit sangat dibutuhkan.Berbagai macam pengobatan semakin berkembang, baik pengobatan modern maupun pengobatan tradisional.

Menurut Undang-Undang Nomor 36 Tahun 2009 tentang Kesehatan Pasal 1 angka 16 bahwa:

Pelayanan kesehatan tradisional merupakan pengobatan dan/atau perawatan dengan cara dan obat yang mengacu pada pengalaman dan ketrampilan turun temurun secara empiris yang dapat dipertanggungjawabkan dan diterapkan sesuai dengan norma yang berlaku di masyarakat.

Pengobatan tradisional merupakan penyedia jasa bagi masyarakat.Praktik pengobatan tradisional diharapkan selain menyembuhkan dan memulihkan sakit bagi konsumennya juga harus menjamin kepastian hukum, bahwa usaha yang dijalankannya menggunakan standar usaha pengobatan yang layak dan dapat diterima oleh masyarakat. Walaupun UndangUndang Perlindungan Konsumen belum sepenuhnya melindungi hak-hak pasien pengobatan tradisional, karena perlindungan konsumen di Indonesia masih terpaku pada perlindungan terhadap konsumen pengguna barang dan jasa pada bidang industri.

Hal ini tentu saja merugikan bagi para pemanfaat jasa pengobatan tradisional karena belum adanya perlindungan hukum terhadap hak-hak sebagai konsumen. Apalagi hingga kini pengobatan tradisional 
belum dilengkapi atur main yang jelas. Pengobatan tradisional juga tidak mempunyai standar pengobatan untuk dijadikan acuan, seperti halnya standar pengobatan yang dimiliki oleh pengobatan konvensional.

\section{Menurut Peraturan Pemerintah} Nomor 103 Tahun 2014 tentang Pelayanan Kesehatan Tradisional seorang pengobat tradisional harus mempunyai Surat Izin Praktik Tenaga Kesehatan Tradisional. Menurut Pasal 1 angka 5 Peraturan Pemerintah Nomor 103 Tahun 2014 tentang Pelayanan Kesehatan Tradisional dinyatakan bahwa:

Surat Terdaftar Penyehat
Tradisional yang selanjutnya
disingkat STPT adalah bukti
tertulis yang diberikan kepada
penyehat tradisional yang telah
mendaftar untuk memberikan
Pelayanan Kesehatan Tradisional
Empiris.

Bentuk-Bentuk Aspek Legalitas Bagi Pelayanan KesehatanTradisional dan Masyarakat

Hukum dikatakan telah memberikan perlindungan apabila sudah ada pengaturan tentang hak-hak subjek hukumnya. Artinya, bentuk-bentuk perlindungan hukum dapat dimengerti dari hak-hak subjek hukum yang telah diatur dalam peraturan perundang-undangan.
Berdasarkan Pasal 28 PeraturanPemerintah No. 103 Tahun 2014 tentang hak-hak penyehat tradisional dan klien serta hak-hak tenaga kesehatan tradisional dan klien, bentuk perlindungan hukum bagi penyehat tradisional dalam memberikan pelayanan kesehatan tradisional empiris meliputi:

a. memperoleh informasi yang lengkap dan jujur dari klien atau keluarganya;

b. menerima imbalan jasa; dan

c. mengikuti pelatihan promotif bidang kesehatan.

Berdasarkan Pasal 29 Peraturan Pemerintah No. 103 Tahun 2014, aspek hukum bagi tenagakesehatan tradisional dalam memberikan pelayanan kesehatan tradisional komplementer meliputi:

1. memperoleh pelindungan hukum sepanjang melaksanakan tugas sesuai dengan standar profesi, standar pelayanan, dan standar prosedur operasional;

2. memperoleh informasi yang lengkap dan jujur dari pasien/klien atau keluarganya; dan

3. menerima imbalan jasa.

Terdapat perbedaan bentuk aspek legal antara penyehat tradisional dengan tenaga kesehatan tradisional, yakni penyehat tradisional memiliki hak untuk mengikuti pelatihan promotif bidang kesehatan sedangkan bagi tenaga kesehatan tradisional tidak ditentukan hak 
tersebut. Tenagakesehatan tradisional memiliki hak memperoleh pelindungan hukum sepanjang melaksanakan tugas sesuai dengan standar profesi, pelayanan, dan prosedur operasional, sedangkan bagi penyehat tradisional tidak ada ketentuan tentang hak tersebut.

\section{PENUTUP}

\section{Kesimpulan}

Hasil penelitian menunjukkan bahwa perlindungan hukum bagi penyehat tradisional lebih rendah dibandingkan dengan perlindungan hukum bagi tenaga kesehatan tradisional.Terdapat perbedaan bentuk perlindungan hukum bagi penyehat tradisional dengan tenaga kesehatan tradisional dan perbedaan perlindungan hukum bagi klien/pasien penyehat tradisional dengan klien/pasien tenaga kesehatan tradisional.

\section{Saran}

Dengan adanya peraturan tentang pelayanan kesehatan tradisional dalamUU No 36 tahun 2009 merupakan suatu bentuk komitmen pemerintah dalam memberikan perlindungan bagi pelayanan kesehatan tradisional. Walaupun belum mengatur secara khusus tentang bentuk perlindungannya, namun hal tersebut dapat ditafsirkan secara tersirat.

\section{DAFTAR PUSTAKA}

\section{Buku}

Cecep Triwibowo, Etika \& HukumKesehatan, Yogyakarta: Medical Book, 2014

M. Hadjon, Phillipus. PerlindunganHukum Bagi Rakyat Indonesia.Surabaya: PT. Bina Ilmu, 1988.

Mertokusumo, Sudikno ,Mengenal Hukum; Suatu Pengantar.Yogyakarta: Liberty, 1999

Raharjo, Satijipto ,Ilmu Hukum. Bandung:PT. Citra Aditya Bakti, 2000 .

Sasongko, Wahyu, KetentuanKetentuanPokok Hukum

PerlindunganKonsumen. Bandar Lampung: Universitas Lampung, 2007.

Yuliati.2005.Kajian Yuridis Perlindungan Hukum Bagi Pasien Dalam UndangUndang RI Nomor 29 Tahun 2004 Tentang Praktik Kedokteran Berkaitan Dengan Malpraktik. Malang: Fakultas Hukum Universitas Brawijaya. 2005

Yunanto, Ari. Hukum Pidana Malpraktik Medik (Tinjauan dan Perspektif Medikolegal).Yogyakarta: Andi ,2010

\section{Jurnal}

Agustina, Bunga. "Kewenangan Pemerintah Dalam Perlindungan Hukum Pelayanan Kesehatan Tradisional Ditinjau Dari UndangUndang Republik Indonesia Nomor 36 Tahun 2009 tentang Kesehatan". Dalam Jurnal Wawasan Hukum, Vol. 32 No. 1, Februari, 2015.

B Randang, Frangkiano. "Model Perlindungan Hukum Bagi Pelaku Pengobatan Tradisional". Dalam Jurnal Lex Privatum Vol. 
V/No.2/Mar-Apr 2017.Vol. 1 No. 1 Juni 2018

Nurani Ajeng Tri Utami, Nayla AlawiyaKartika, Dian, dkk. "Pelayanan KesehatanTradisional dan PerlindunganHukum Bagi Pasien".SOEPRAJurnal Hukum Kesehatan. Vol 2,No 1, 2016.

Muchsin, Achmad. "Perlindungan Hukumterhadap Pasien Sebagai KonsumenJasa Pelayanan Kesehatan dalamTransaksi

Terapeutik".JurnalHukum Islam (JHI). Vol 7, No 1,Juni 2009.

Rarung, Lavenia. "Tanggung JawabHukum Terhadap Pelaku PembuatObatObatan Tradisional DitinjauDari Undang-Undang Nomor 36Tahun 2009 Tentang Kesehatan",Jurnal Lex Crimen. Vol. VI No. 3,Mei 2017

Soetoprawiro, Koermiatmanto. "Peraturan Perlindungan Hak-hak Perempuan dan Anak-Anak dalam Hukum Kearganegaraan Indonesia”. Jurnal Hukum Pro Justisia XX nomor Juli2002.

\section{Perundang-Undangan}

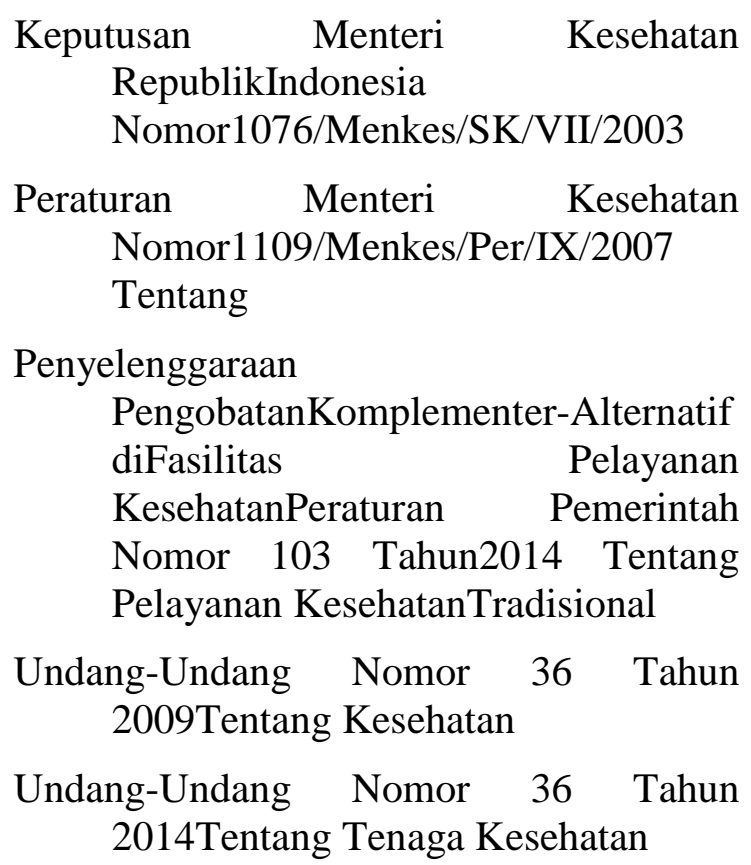

